\title{
A SPECIALIZED TOPAZ-BEARING RAPAKIVI GRANITE AND ASSOCIATED MINERALIZED GREISEN IN THE AHVENISTO COMPLEX, SE FINLAND
}

\author{
PETER EDÉN
}

\begin{abstract}
EDÉN, PETER, 1991: A specialized topaz-bearing rapakivi granite and associated mineralized greisen in the Ahvenisto complex, SE Finland. Bull. Geol. Soc. Finland 63, Part. 1, 25-40.

The Ahvenisto rapakivi complex is a satellite northwest of the large Wiborg rapakivi batholith in Southeastern Finland. The rapakivi rocks are surrounded by rapakivi-age gabbros, anorthosites, monzodiorites and diabases. The complex consists of a highly evolved suite of several texturally, mineralogically and geochemically different rapakivi types. They are anorogenic and their age is 1640-1630 Ma.

The youngest phases of the rapakivi suite are even-grained, topaz-bearing and geochemically specialized tin granites. They also show the characteristics of A-type granites. Earlier known rapakivi granites in Finland of the same type have been described from Eurajoki and Kymi.

These specialized Kuusisuo granites are highly evolved microcline-albite granites, which are modified by many (auto)metasomatic and late/postmagmatic alteration reactions. They have high $\mathrm{Si}, \mathrm{F}, \mathrm{Li}, \mathrm{Rb}, \mathrm{Sn}, \mathrm{Nb}, \mathrm{Th}$ and $\mathrm{U}$, and low/extremely low $\mathrm{Ti}, \mathrm{Fe}, \mathrm{Mg}, \mathrm{Ca}, \mathrm{P}, \mathrm{Zr}, \mathrm{Ba}, \mathrm{Sr}$ and $\mathrm{La}$. They intrude earlier phases of rapakivi granites as a small cupola, which in its upper parts is altered to topaz-bearing rapakivi and mineralized topaz-greisen. Mineralized greisen veins occur in the surrounding rapakivi granites. The uneconomic mineralizations contain $\mathrm{SnO}$ and sulphides of $\mathrm{Cu}, \mathrm{Zn}$ and As.
\end{abstract}

Key words: granites, rapakivi, topaz, greisen, chemical composition, tin, Proterozoic, Kuusisuo, Heinola, Finland.

Peter Edén: Åbo Akademi University, Department of Geology and Mineralogy, SF-20500 Ảbo, Finland

\section{Introduction}

Rapakivi granites and associated diabase dykes, gabbros and anorthosites form a belt from the Ukraine over Fennoscandia, Greenland and Labrador to the central and southwestern parts of the United States. They are anorogenic and 1750-1400 Ma old (e.g. Emslie 1978, Anderson 1983). In Finland there are four large rapakivi batholiths, the Wiborg, Åland, Vehmaa and
Laitila batholiths, and several smaller, at times polyphase satellites, e.g. the Suomenniemi and Ahvenisto batholiths and the Eurajoki stock (Fig. 1).

The latest phases of the rapakivi granites in Finland have for a long time been known as potential tin granites. Uneconomic mineralizations of $\mathrm{Sn}, \mathrm{Be}, \mathrm{W}, \mathrm{Pb}$ and $\mathrm{Zn}$ have earlier been described from the topaz-bearing, latest intrusive phases in Eurajoki in W Finland and in Kymi in 


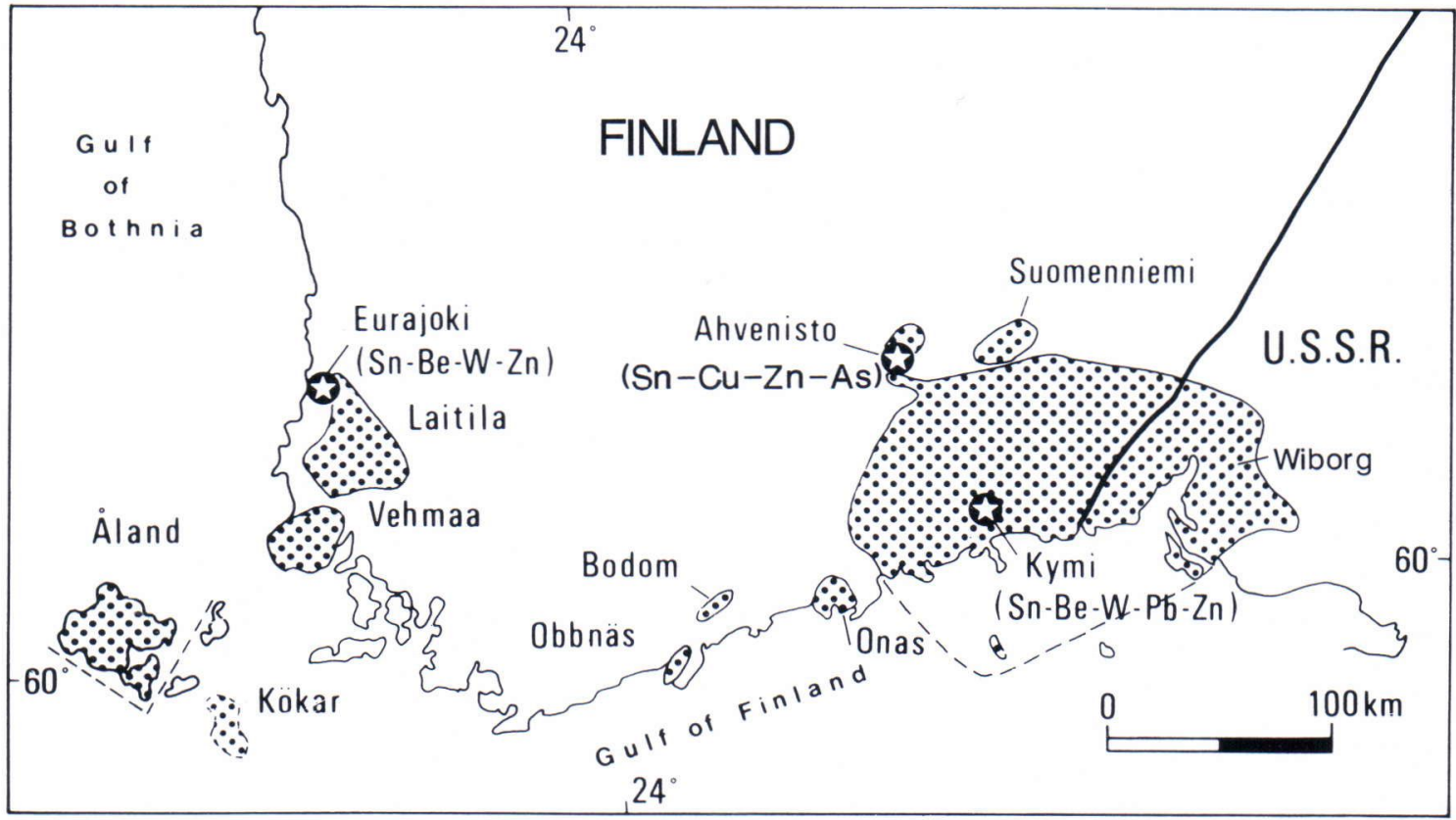

Fig. 1. The rapakivi granites in southern Finland and associated mineralizations (Nurmi \& Haapala 1986, modified).

the Wiborg batholith (Haapala 1974, 1977a, 1977b, 1988) (Fig. 1). Mineralized greisen veins occur in the Åland batholith (Bergman 1981).

In 1978 Rautaruukki Oy, a steel and mining company, started prospecting for tin in the surroundings of the rapakivi areas. Geochemistry of the heavy-mineral fraction of till was used in the reconnaissance phase of this exploration. A distinct $\mathrm{Sn}$ anomaly was found in the southern parts of the Ahvenisto area and between this complex and the Wiborg batholith (Mattila and Peuraniemi 1980, Peuraniemi et al. 1984).

Further investigations in the Kuusisuo area in the southern part of the Ahvenisto rapakivi complex including detailed mapping, percussion drilling and diamond drilling, revealed greisen veins in the outcrops and mineralized greisen bodies associated with a previously unknown, topaz-bearing type of rapakivi in the drill holes (Edén 1980, 1987, Mattila 1983, 1985, Peuraniemi et al. 1984).

This paper describes the most evolved rapaki- vi types in the Ahvenisto area. They consist of a topaz-bearing granite and its topaz-free parts, together called the Kuusisuo granites, and associated greisen. The slightly less evolved Mannila granites are also described. The older types of biotite rapakivi granite in the surroundings are only briefly discussed.

About 200 chemical analyses were made on XRF and AAS at Rautaruukki Oy in Raahe. Some micro-probe analyses were made with a JEOL JSM-35 instrument at the University of Oulu.

\section{The Ahvenisto Rapakivi complex}

The entire Ahvenisto complex, including the basic members, has been described by Savolahti (1956). The biotite rapakivi granites occupy an area of about $240 \mathrm{~km}^{2}$ and are in north and east surrounded by a horse-shoe shaped body of gabbro, anorthosite, (quartz)monzodiorite, dia- 
Fig. 2. Geological map of the Ahvenisto complex (modified from Savolahti 1956, Johansson 1984). PR = porphyritic biotite rapakivi, HPR = hornblende-bearing porphyritic biotite rapakivi, $\mathrm{PA}=$ porphyry aplite, $\mathrm{H}=$ hornblende rapakivi, GA = gabbroanortosite, $\mathbf{M}=$ (quartz)monzodiorite, $\mathrm{Q}=$ quartz porphyry, $\mathrm{D}=$ diabase.

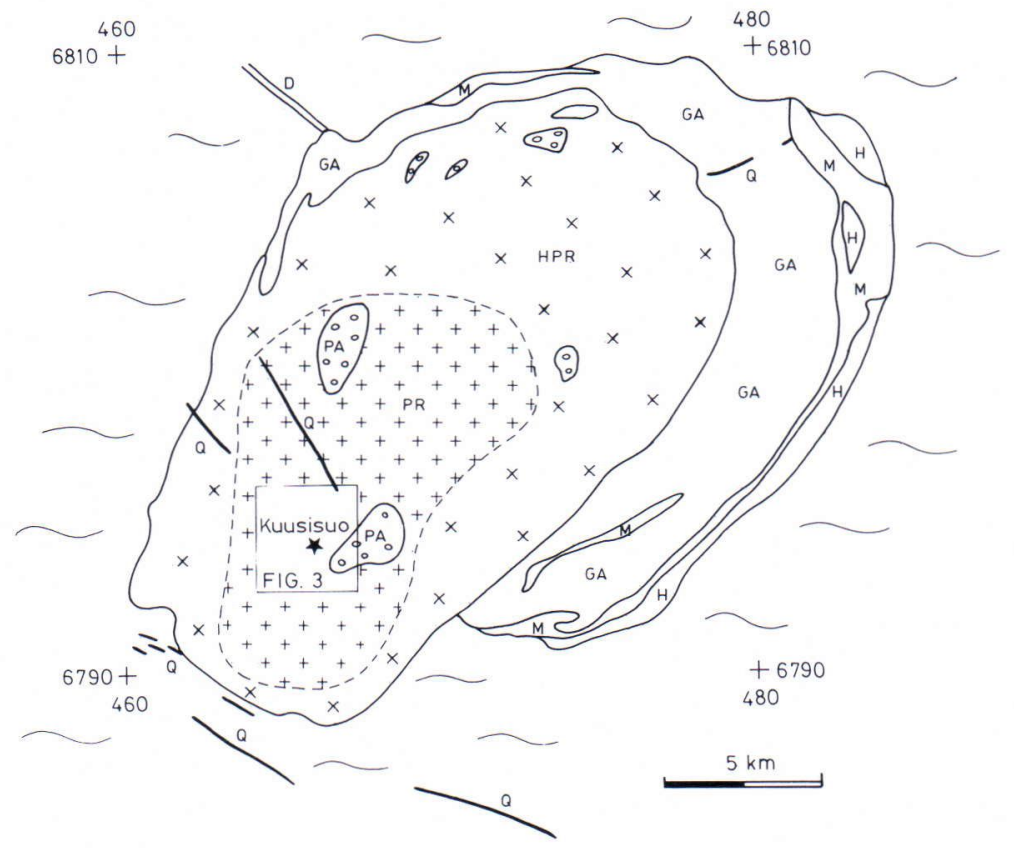

base and a narrow body of hornblende rapakivi along the easternmost border (Fig. 2). The basic rocks are slightly older than the rapakivi granites, because the latter cut and brecciate the former (Savolahti 1956, Johansson 1984). A swarm of diabase dykes of approximately the same age as the rapakivi granites runs in a WNW direction from the complex (Laitakari 1987).

The rapakivi granites in the Ahvenisto complex are coeval with the main phases of the Wiborg batholith, and their age is 1640-1630 Ma. The latest phases may, however, be of approximately the same age as the Kymi cupola, which has been described as the youngest intrusion phase in the Wiborg batholith (Vaasjoki 1977, Vaasjoki et al. 1989). The Ahvenisto rapakivi complex is thought to be connected with the main batholith at a shallow depth. Laurén $(1968,1970)$ has interpreted gravity data as if beneath Ahvenisto there is a $18 \mathrm{~km}$ deep $\gg$ root» of the otherwise 5-10 km thick, laccolith-like Wiborg batholith. According to the newest in- terpretations of geophysical data, the Ahvenisto batholith is a cupola »standing up» above the sheet-formed Wiborg batholith (Elo and Tuomi 1989).

According to Savolahti (1956) a partly porphyritic biotite rapakivi forms the main part of the Ahvenisto complex. In the present author's opinion most of the rapakivi complex is porphyritic biotite rapakivi. The rock has angular, or sometimes rounded, megacrysts $(1-3 \times 3-$ $6 \mathrm{~cm}$ ) of $\mathrm{K}$-feldspar in a coarse- to mediumgrained matrix of K-feldspar, quartz, plagioclase and biotite-chlorite. The typical rapakivi texture, rounded megacrysts of $\mathrm{K}$-feldspar with a mantle of plagioclase, is totally absent. At the borders of the complex abundant hornblende and sometimes even fayalite occur. Fluorite and in smaller amounts zircon, apatite and opaques are typical accessories. Sericite, chlorite and muscovite are common alteration products.

The biotite rapakivi consists of several intrusions or subphases. The inner parts of the com- 
plex, at least in the south, are built up of geochemically more evolved phases. They are slightly finer grained, some are even-grained, and none contain hornblende (Edén 1980, 1987).

Small bodies of porphyry aplite occur in many places in the complex (Fig. 2). Mineralogically these rocks are identical with the porphyritic biotite rapakivi. The K-feldspar megacrysts are, however, both smaller and less abundant and occur in a fine- to mediumgrained groundmass. Rounded quartz inclusions, myrmekite and graphic textures are common. The contacts with the porphyritic rapakivi can be either sharp, without chilled margins, or fully gradational.

The chemical composition of the porphyry aplites exhibits the same range of composition as the different types of porphyritic biotite rapakivi. Each porphyritic rapakivi phase seems to have its own chemically similar porphyry aplite. This has not, however, been exactly verified. Most porphyry aplites are horizontal or vertical sheetlike intrusions, probably formed during block movements.

Quartz porphyry dykes of varying length and width occur both inside and outside the rapakivi complex, but not in the area with the youngest rapakivi phases. Some aplites, and more seldom pegmatites, also occur.

The youngest intrusive phases, which occur in the southern part of the rapakivi complex, in Kuusisuo and its surroundings, are described below.

\section{The Kuusisuo and Mannila granites}

This paper focusses on the small Kuusisuo area and its surroundings in the southern part of the Ahvenisto rapakivi complex (Fig. 2, 3). Here, unlike in the bulk of the complex, outcrops are very few. The granites are mostly late phases of biotite rapakivi and porphyry aplites and in many outcrops there occur greisen veins $0.5-10 \mathrm{~cm}$ wide.

In the NW part of the study area there are some geochemically quite strongly evolved rapakivi granites, here called the Mannila granites. They include a wide variety of textural types but geographically they are restricted to a small area or to inferred fracture/ fault zones. They are either fine-grained and even-grained, medium-grained with a few phenocrysts of $\mathrm{K}$ feldspar and quartz, or even coarse-grained and porphyritic. Miarolitic cavities and pegmatitic bodies occur commonly, especially in the finegrained type, and all types have some secondary topaz. The fine-grained types are younger than the porphyritic ones.

Several drill holes penetrated rock types previously unknown in the Ahvenisto complex. They consist of an even- and medium-grained rapakivi granite, which in its upper parts is topazbearing (Fig. 3, 4). In the uppermost parts it is altered to greisen and mineralized. These Kuusisuo granites represent the youngest intrusive phase in Ahvenisto, and may thus be of approximiately the same age as the Kymi cupola. The Mannila granites are both chemically and spatially closely related to the Kuusisuo granites.

The full size of the Kuusisuo granites and their lower parts is not known, but the area penetrated by the drill holes is only about $100 \times 100 \mathrm{~m}$. The distribution of the greisen veins observed in outcrops and drill holes suggests that they form a long and narrow ridge or several bulges along the same axis in a NNE-SSW direction (Fig. 3). It is also uncertain, whether the granitic parts ever reach the surface. The greisenized upper part does so in two drillholes (R 4 and R 7) (Fig. 3, 4).

\section{Petrography of the granites and greisens}

The coarse, porphyritic type of the Mannila granites cannot easily be distinguished macroscopically from the porphyritic biotite rapakivi. It is reddish and has white or glassy quartz. Certain identification is only achieved through chemical analysis.

All Mannila granites are quite strongly altered. The K-feldspar is strongly pigmented and altered 


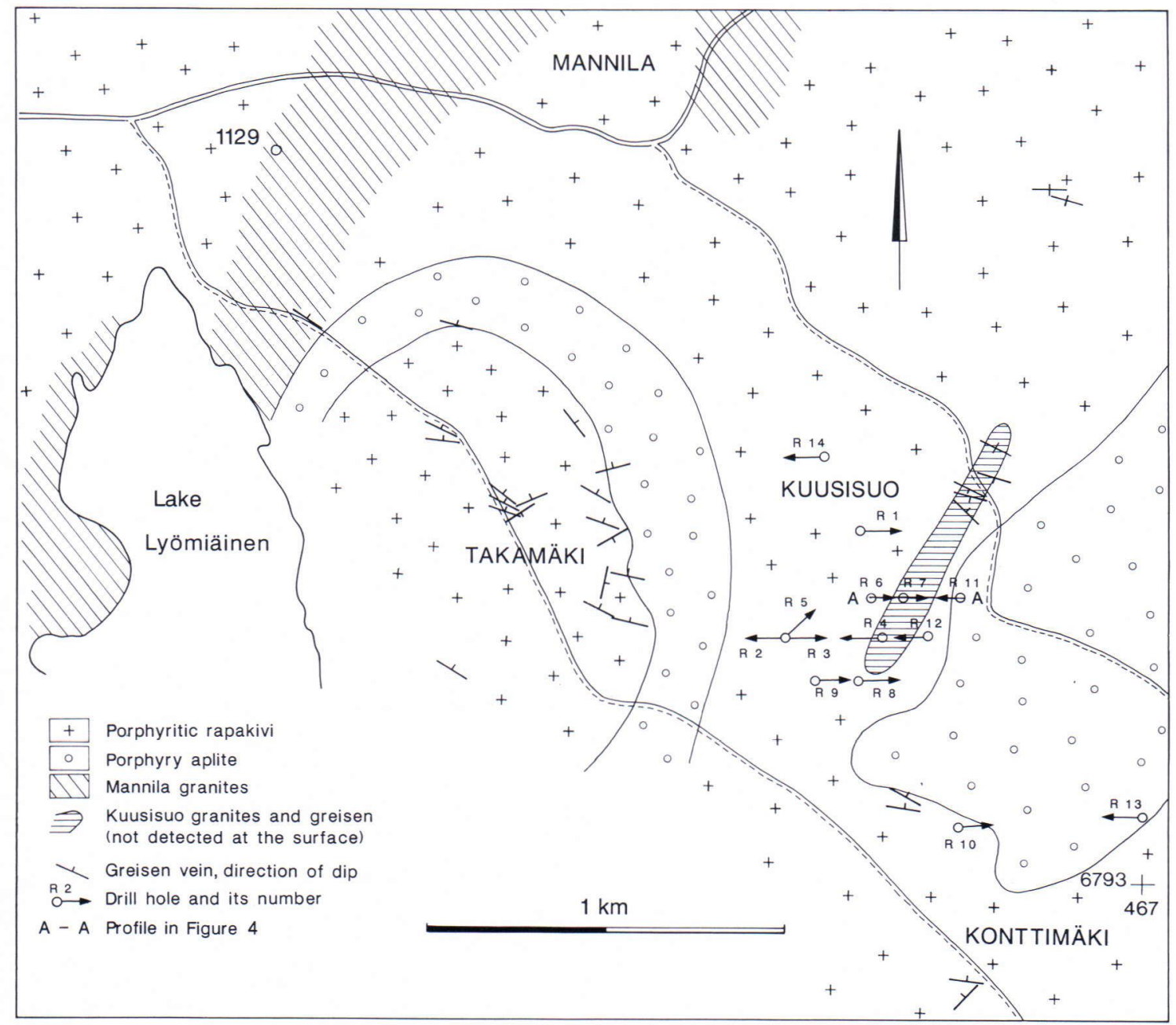

Fig. 3. Geological map of the Kuusisuo area.

to plagioclase, muscovite, chlorite and quartz. The plagioclase is either fresh and secondary albite or altered to sericite-muscovite. Chlorite and fluorite are also common alteration products. Some topaz is always found in thin sections and partly it seems to be primary. Zircon is absent.

The topaz-bearing Kuusisuo rapakivi granite and the topaz-free type, here called mediumgrained rapakivi, are even-grained and mediumgrained. In fact it is one and the same granite, which in its upper parts has undergone au- tometasomatic and subsolidus reactions and become topaz-bearing. The medium-grained type has been found only in one drill hole (R 12), while the topaz-rapakivi is found in four holes ( $\mathrm{R}$, R 7, R 11 and R 12).

The Kuusisuo granites are reddish and their grain size is $1-2 \mathrm{~mm}$. The main minerals are quartz, K-feldspar and plagioclase (Table 1). In the topaz-rapakivi topaz and biotite-chlorite also occur in amounts of about $5 \%$ each. Instead it has $10 \%$ less $\mathrm{K}$-feldspar than the medium- 
A

A

R6

R7

$\mathrm{R} 11$

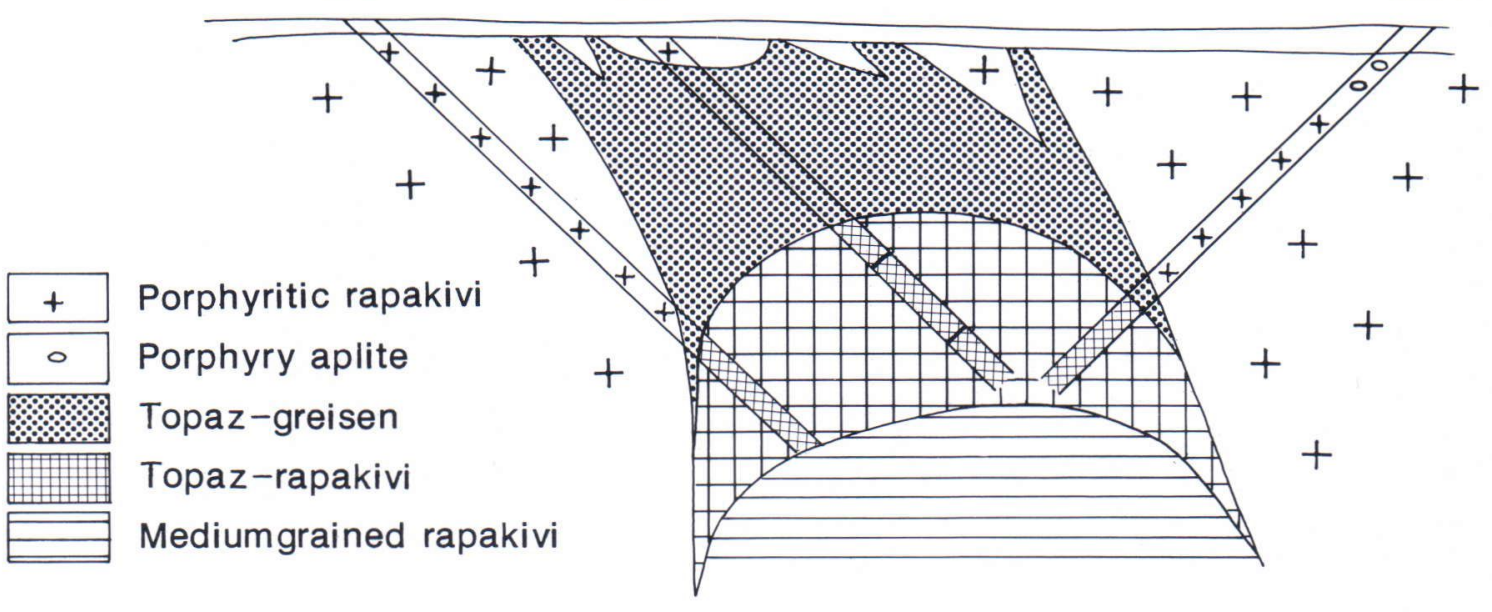

$100 \mathrm{~m}$

Fig. 4. Profile from three drill holes through the Kuusisuo granites and the topaz-greisen.

grained rapakivi. The medium-grained type contains very little mica, and most of it is muscovite. The topaz-rapakivi has $1.5 \%$ fluorite, or twice as much as the medium-grained rapakivi. Both types have more plagioclase than rapakivi normally has.

Typical accessories are cassiterite and sulphides. In the topaz-rapakivi monazite is also frequently occurring. Zircon is almost totally ab-

Table 1. The modal composition of the Kuusisuo granites. Aritmetic mean and variation. (800 points)

\begin{tabular}{lrr}
\hline & Topaz-bearing (6) & Mediumgrained (3) \\
\hline K-feldspar & $24.5(18.6-34.4)$ & $34.0(27.5-39.2)$ \\
Quartz & $33.9(28.2-41.3)$ & $34.2(23.7-43.2)$ \\
Plagioclase & $27.8(21.0-31.3)$ & $28.8(25.5-34.0)$ \\
Biotite + chlorite & $5.0(0.8-7.5)$ & $0.1(0.0-0.3)$ \\
Muscovite & $1.7(0.2-5.0)$ & $1.6(1.2-2.3)$ \\
Topaz & $5.0(2.4-6.8)$ & 0.0 \\
Fluorite & $1.5(0.2-4.9)$ & $0.7(0.3-1.0)$ \\
Accessories & $0.6(0.5-0.6)$ & $0.6(0.5-0.7)$ \\
\hline \multicolumn{3}{c}{100.0} \\
\hline
\end{tabular}

sent. The topaz-bearing phases in Eurajoki and Kymi also have bastnaesite, ilmenite, columbite and thorite as typical accessories (Haapala 1974, 1988).

Both types of the Kuusisuo granites typically contain coarse-grained aggregates of quartz, feldspar, micas and varying amounts of fluorite, chalcopyrite, cassiterite, sphalerite, pyrite and arsenopyrite.

Quartz and plagioclase are subhedral-anhedral, while the $\mathrm{K}$-feldspar fills the space between them. In places quartz grains up to $5 \mathrm{~mm}$ occur. The plagioclase is mostly clear albite, some is slightly altered to sericite. The K-feldspar in the medium-grained rapakivi is strongly pigmented and is often replaced by albitic plagioclase, but also by quartz and muscovite. Through the pigment perthite and less commonly, the crosshatched twins of microcline can be observed. In the topaz-rapakivi the $\mathrm{K}$-feldspar is more strongly altered and replaced by muscovite-chlorite, plagioclase, quartz, topaz and fluorite. Partly as a re- 
sult of these alterations, there are more micas and less $\mathrm{K}$-feldspar in the topaz-rapakivi than in the medium-grained rapakivi.

Topaz is partly primary and partly it replaces quartz and feldspars. It has a grain size of $0.02-2 \mathrm{~mm}$. The smaller grains often occur in aggregates. Some topaz is altered to muscovite along fractures.

There are three types of mica. They are normal biotite or protolithionite, muscovite and green chlorite. Muscovite and chlorite usually occur as ragged intergrowths.

In an A-P-Q-diagram the granites would plot in the field of "normal granite» (Streckeisen 1967), when all plagioclase is counted as $P$. The fact, that a great part of the plagioclase is albite, with $\mathrm{An}<5$, should move the granites to the fields of syenogranite or alkali feldspar granite. As they hold less than $10 \%$ dark minerals, they could also be called alaskites.

The rapakivi granites at Kuusisuo are greisenized in different ways and to varying degrees. Greisen veins occur in the outcrops and in almost all drill holes. Larger greisen bodies are penetrated in some drill holes.

In drill holes R 4 and R 7 a greisen body is penetrated for tens of meters. In hole $\mathrm{R} 6$ it is about $10 \mathrm{~m}$ thick (Fig. 4). Topaz is typical for this greisen, and accordingly it is called topazgreisen. This greisen is usually grey, mediumgrained and homogenous; only seldom coarsegrained aggregates are observed. The topazgreisen seems to change gradually downwards to topaz-rapakivi. This gradation is well displayed in drill hole $\mathrm{R} 7$.

Quartz makes up about $50 \%$ of the topazgreisen, micas about $30 \%$ and topaz about $15 \%$. Feldspars are almost totally absent. Topaz occurs both as aggregates of small grains and as bigger individual grains. The micas are the same as in the topaz-rapakivi, i.e. biotite or protolithionite and intergrown muscovite and chlorite. Accessory minerals are fluorite, monazite, cassiterite, chalcopyrite, sphalerite, pyrite, xeno- time and arsenopyrite. The coarse-grained aggregates are enriched in ore minerals.

In the middle of hole R 3 and in the lower end of hole $\mathrm{R} 4$ there is a $10-30 \mathrm{~m}$ thick rock type called sericite-greisen. Preserved relic textures show, that it is an alteration product of a porphyritic rapakivi. It has megacrysts $(1-4 \mathrm{~cm})$ of altered $\mathrm{K}$-feldspar in a finer, heterogenous mass of sericite, fluorite, quartz, K-feldspar, chlorite and opaques. Monazite is a typical accessory, others are e.g. cassiterite and carbonate. Topaz is absent in this greisen type.

In the outcrops greisen veins $1-10 \mathrm{~cm}$ in width are found. In the drill holes there are also much thicker veins. Towards the outer regions of the investigated area, there are only thin streaks of greisen and quartz veins.

The greisen veins are dark grey and they usually have a seam of quartz in the middle. Sometimes there is also e.g. chalcopyrite or arsenopyrite in the seam. Mineralogically the veins consist of varying amounts of quartz in a finegrained mass of sericite, muscovite, chlorite, fluorite and ore minerals. Topaz is commonly absent, although the veins look like topaz-greisen. In a few veins some topaz does occur, indicating stronger alteration and a closer similarity to the topaz-greisen.

\section{Geochemical characteristics}

Table 2 gives the chemical composition of the rapakivi granites in the Kuusisuo area. Rapakivi granites differ chemically from normal granites. At Kuusisuo, the difference is even more pronounced, due to magmatic differentiation and fractional crystallization. The $\mathrm{K} / \mathrm{Rb}$ ratio in $\mathrm{Ta}-$ ble 2 is a distinct feature of the fractionation. While this ratio is over 160 for normal granites, the granites at Kuusisuo have much smaller ratios. The ratio of 59 for topaz-rapakivi is according to Groves and McCarthy's (1978) classification a sign of strong fractionation.

Geochemically specialized granites or tin-granites are associated with ores or mineralizations 
Table 2. Chemical composition of the rocks in the Kuusisuo area given as aritmetic means.

\begin{tabular}{|c|c|c|c|c|c|}
\hline & $\begin{array}{c}\text { Porphyritic } \\
\text { (44) }\end{array}$ & $\begin{array}{c}\text { Mannila granites } \\
\text { (10) }\end{array}$ & $\begin{array}{c}\text { Medium-grained } \\
\text { (4) }\end{array}$ & $\begin{array}{c}\text { Topaz-rapakivi } \\
\text { (26) }\end{array}$ & $\begin{array}{c}\text { Topaz-greisen } \\
\text { (47) }\end{array}$ \\
\hline $\mathrm{SiO}_{2}(\%)$ & 72.79 & 76.20 & 75.38 & 73.98 & 71.96 \\
\hline $\mathrm{TiO}_{2}$ & 0.24 & 0.09 & 0.014 & 0.017 & 0.019 \\
\hline $\mathrm{Al}_{2} \mathrm{O}_{3}$ & 13.35 & 12.37 & 13.60 & 14.03 & 14.37 \\
\hline $\mathrm{Fe}_{2} \mathrm{O}_{3}^{*}$ & 1.24 & 0.76 & 0.25 & 0.83 & 1.87 \\
\hline $\mathrm{FeO}^{*}$ & 1.40 & 0.88 & 0.27 & 1.04 & 3.67 \\
\hline $\mathrm{MnO}$ & 0.04 & 0.02 & 0.01 & 0.04 & 0.14 \\
\hline $\mathrm{MgO}$ & 0.17 & 0.04 & 0.00 & 0.01 & 0.01 \\
\hline $\mathrm{CaO}$ & 1.02 & 0.59 & 0.65 & 0.70 & 0.96 \\
\hline $\mathrm{Na}_{2} \mathrm{O}$ & 2.58 & 2.91 & 3.72 & 2.82 & 1.09 \\
\hline $\mathrm{K}_{2} \mathrm{O}$ & 6.06 & 5.39 & 5.39 & 4.88 & 2.93 \\
\hline $\mathrm{P}_{2} \mathrm{O}_{5}$ & 0.06 & 0.02 & 0.02 & 0.01 & 0.01 \\
\hline $\mathrm{Cu}(\mathrm{ppm})$ & 36 & 22 & 80 & 260 & 478 \\
\hline $\mathrm{Zn}$ & 70 & 50 & 16 & 470 & 852 \\
\hline Sn & 12 & 10 & 10 & 40 & 185 \\
\hline $\mathrm{U}$ & 7 & 8 & 8 & 10 & 15 \\
\hline $\mathrm{Th}$ & 62 & 63 & 42 & 40 & 28 \\
\hline $\mathrm{Nb}$ & 35 & 39 & 72 & 80 & 82 \\
\hline $\mathrm{Zr}$ & 327 & 180 & 78 & 70 & 66 \\
\hline $\mathrm{Ba}$ & 391 & 160 & 75 & 70 & 43 \\
\hline $\mathrm{Sr}$ & 65 & 35 & 20 & 20 & 27 \\
\hline $\mathrm{La}$ & 78 & 63 & 12 & 20 & $<10$ \\
\hline $\mathrm{Ce}$ & 209 & 180 & 92 & 100 & 82 \\
\hline $\mathrm{Li}$ & $74(16)$ & $64(8)$ & 28 & 210 & 852 \\
\hline $\mathrm{F}$ & $6772(36)$ & $3950(8)$ & 6000 & 14270 & 33080 \\
\hline $\mathrm{Rb}$ & $404(25)$ & $419(9)$ & $455(2)$ & $740(21)$ & $1080(37)$ \\
\hline $\mathrm{K} / \mathrm{Rb}$ & $126(25)$ & 104(9) & $92(2)$ & $59(21)$ & \\
\hline $\mathrm{Mg} / \mathrm{Li}$ & 15 & 12 & $<1$ & $<1$ & $<1$ \\
\hline $\mathrm{Na} / \mathrm{K}$ & 0.38 & 0.48 & 0.63 & 0.53 & 0.35 \\
\hline \multirow[t]{2}{*}{$\mathrm{A} / \mathrm{CNK}$} & $0.95-$ & $0.99-$ & $1.02-$ & $1.07-$ & \\
\hline & 1.29 & 1.18 & 1.05 & 1.55 & \\
\hline
\end{tabular}

* Calculated from Fe according to Le Maitre (1982)

of e.g. Sn, W, Zn, Cu, Be and $\mathrm{Li}$ and have common geochemical characteristics distinguishing them from other granites (see Tischendorf 1977; Taylor 1979). The Kuusisuo granites exhibit many of these characteristics.

Compared with »normal» granites, the granites at Kuusisuo have high contents of $\mathrm{SiO}_{2}$, $\mathrm{K}_{2} \mathrm{O}, \mathrm{F}, \mathrm{Rb}, \mathrm{Li}, \mathrm{Sn}, \mathrm{Nb}, \mathrm{U}$ and Th. The contents still increase towards the youngest differentiates. $\mathrm{Zr}$ and $\mathrm{Ce}$ are high in the porphyritic rapakivi and the porphyry aplites, but are depleted in the late Mannila and Kuusisuo granites.

The granites are depleted in $\mathrm{TiO}_{2}, \mathrm{Fe}_{2} \mathrm{O}_{3}$, $\mathrm{FeO}, \mathrm{MgO}, \mathrm{CaO}, \mathrm{MnO}, \mathrm{P}_{2} \mathrm{O}_{5}$, $\mathrm{La}, \mathrm{Ba}$ and $\mathrm{Sr}$. $\mathrm{TiO}_{2}, \mathrm{MgO}, \mathrm{Zr}$, La, Ba and $\mathrm{Sr}$ are extremely low in the youngest phases. The ratios of $\mathrm{K} / \mathrm{Rb}$, $\mathrm{Mg} / \mathrm{Li}$ and $\mathrm{Na} / \mathrm{K}$ are also low. The latest phases, the Kuusisuo granites, thus have the geochemical features of tin-granites (cf. Tischendorf 1977).

There are two geochemically different and geographically separated porphyry aplites (not given in Table 2) in the Kuusisuo area (Fig. 3). The one in E-SE is geochemically identical with the porphyritic rapakivi, while the other one at Takamäki in W is geochemically less evolved.

The Mannila rapakivi granites fall geochemically between the porphyritic biotite rapakivi and the Kuusisuo granites with respect to most elements. But they have very low $\mathrm{TiO}_{2}, \mathrm{MgO}, \mathrm{CaO}$ and $\mathrm{P}_{2} \mathrm{O}_{5}$, resembling the Kuusisuo granites in 
Fig. 5. Alkalies vs silica of the granites in the Kuusisuo area. The alkalic/subalkalic boundary from Miyashiro (1978).

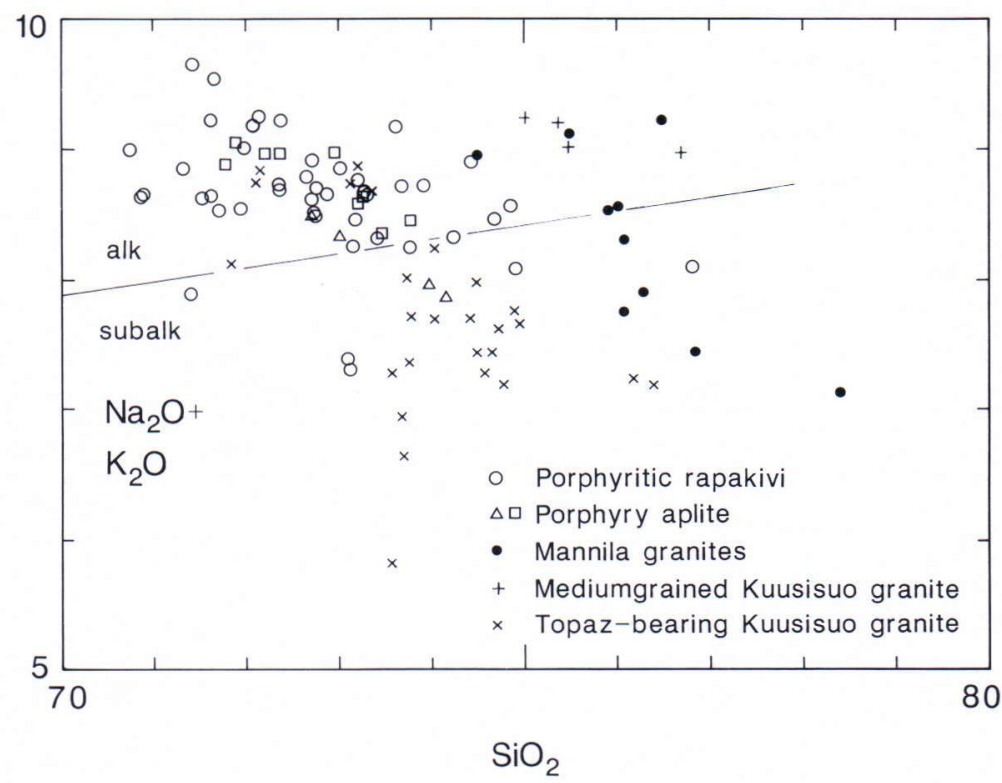

this respect. On the other hand they have even lower contents than the porphyritic types of the otherwise high $\mathrm{F}$ and $\mathrm{Li}$, resembling the so called precursors of tin granites (Tischendorf 1977).

Compared with the topaz-bearing rapakivi the topaz-greisen has lower $\mathrm{SiO}_{2}, \mathrm{Na}_{2} \mathrm{O}, \mathrm{K}_{2} \mathrm{O}, \mathrm{Ba}$, $\mathrm{K} / \mathrm{Rb}$ and $\mathrm{Na} / \mathrm{K} . \mathrm{Fe}_{2} \mathrm{O}_{3}, \mathrm{FeO}, \mathrm{MnO}, \mathrm{Sn}, \mathrm{Li}$ and $\mathrm{F}$ are much higher and $\mathrm{S}, \mathrm{Cu}, \mathrm{Zn}, \mathrm{U}$ and $\mathrm{Rb}$ higher in the greisen. Most of these changes have started with the change from the medium-grained to the topaz-bearing type. The greisen veins show changes in the same elements but to a smaller extent, taking into account that the altered rock in this case is porphyritic rapakivi.

The topaz-greisen and the greisen veins have increased, in places highly increased, amounts of $\mathrm{Sn}, \mathrm{Cu}, \mathrm{Zn}, \mathrm{As}, \mathrm{W}, \mathrm{Bi}, \mathrm{Li}, \mathrm{F}$ and $\mathrm{Rb}$.

The rapakivi granites in the Kuusisuo area are subalkaline with distinct alkaline affinities (Fig. 5 ). The $\mathrm{Na} / \mathrm{K}$ ratio is low overall, but increases in the youngest phases (Fig. 6). The granites have variable A/CNK values, but the youngest topazgranites are distinctly peraluminous, having values $>1.1$, while the medium-grained type and the Mannila granites usually have values $<1.1$
(Fig. 7). The wide variation is partly due to the alteration reactions, which have changed the contents of $\mathrm{Ca}, \mathrm{Na}$ and $\mathrm{K}$.

The granites, especially the latest phases, show A-type characteristics. Besides the characteristics already mentioned, the granites at Kuusisuo have e.g. high $\mathrm{SiO}_{2}, \mathrm{Na}_{2} \mathrm{O}+\mathrm{K}_{2} \mathrm{O}, \mathrm{Fe} / \mathrm{Mg}, \mathrm{F}, \mathrm{Zr}, \mathrm{Nb}$ and $\mathrm{Sn}$, and low $\mathrm{CaO}, \mathrm{Ba}$ and $\mathrm{Sr}$ (for a definition of A-type granites see Loiselle and Wones 1979, Collins et al. 1982, White and Chappell 1983). They also have corundum in their norms.

The abundances of $\mathrm{SiO}_{2}, \mathrm{Rb}, \mathrm{Ta}$ and $\mathrm{Y}$ show that the granites in Ahvenisto are within plate (WP) granites according to the classification introduced by Pearce et al. (1984).

\section{Discussion and conclusions}

The evolutionary trend; porphyritic rapakivi and porphyry aplite - Mannila granites medium-grained rapakivi - topaz-bearing rapakivi - topaz-greisen, is clearly evident from the geochemical composition. Particularly beautifully it appears in a $\mathrm{Rb}-\mathrm{K} / \mathrm{Rb}$ diagram and in the 


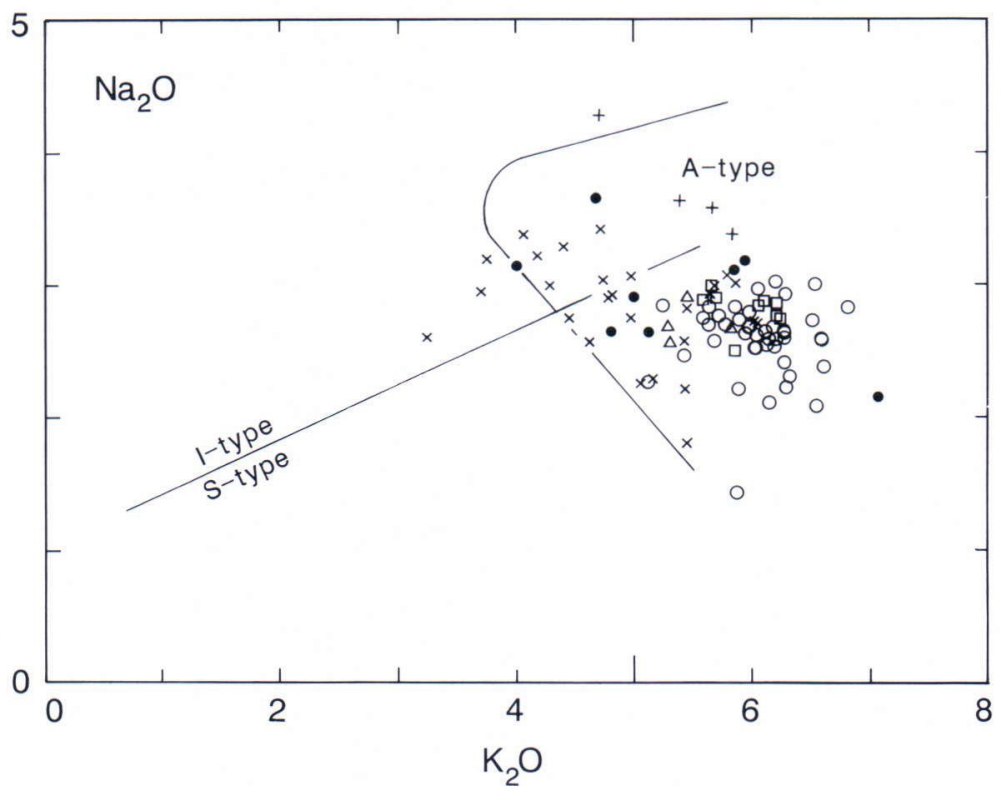

Fig. 6. $\mathrm{Na}_{2} \mathrm{O}-\mathrm{K}_{2} \mathrm{O}$ diagram of the granites in the Kuusisuo area. I-S line and A curve based on White \& Chappell (1983). Symbols as in Fig. 5. trace element diagrams of $\mathrm{Ba}-\mathrm{Rb}-\mathrm{Sr}$ and $\mathrm{Ti}-\mathrm{Zr}$ (Fig. 8, 9 and 10).

The evolution can be seen as a gradual change in chemical composition. Some oxides and elements show a distinct gap between different granite types, while others are overlapping. Besides the evolution from type to type, there is also fractionation within the different phases.

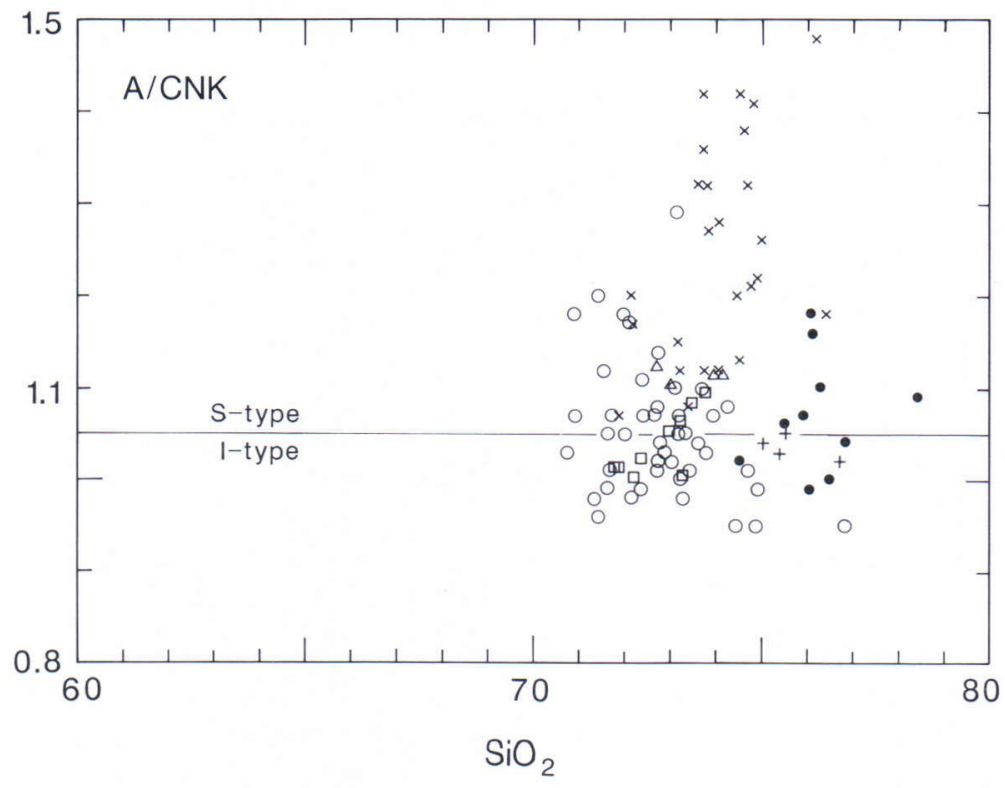

Fig. 7. Alumina saturation-silica diagram of the granites in the Kuusisuo area. I-S line after White \& Chappell (1983). Symbols as in Fig. 5. 
Fig. 8. Rb-K/Rb diagram showing the fractionation of the granites in the Kuusisuo area. Symbols as in Fig. 5.

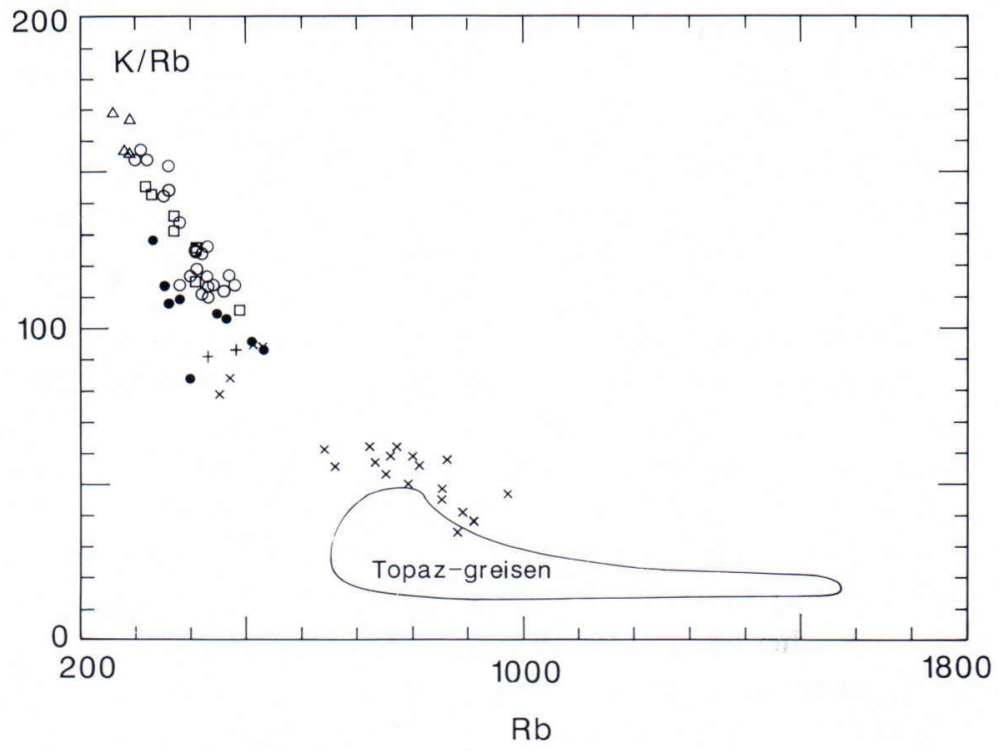

(Auto)metasomatic and postmagmatic alteration reactions have worked in the same direction, narrowing the possible gaps in composition. This may explain why the Mannila granites overlap the

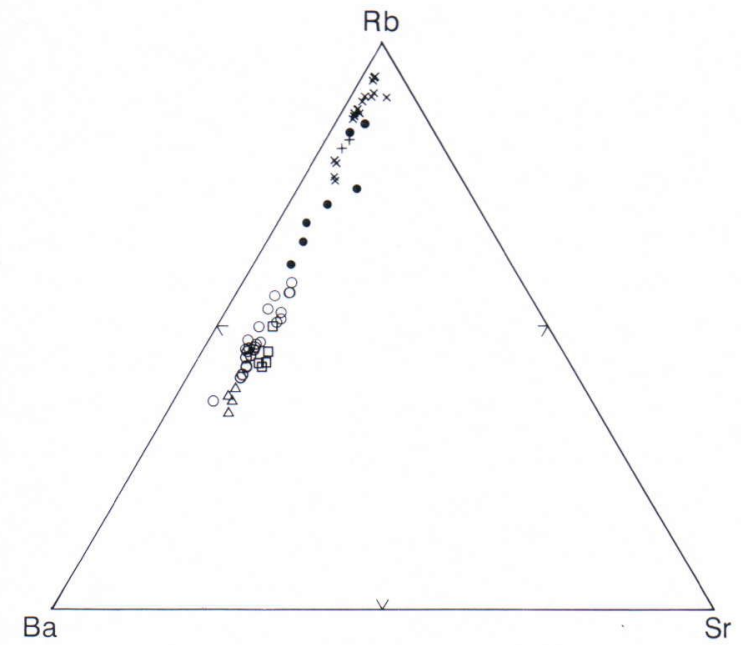

Fig. 9. Rb-Ba-Sr diagram showing the trends of the granites in the Kuusisuo area. Symbols as in Fig. 5.
Kuusisuo granites in some diagrams. They have been altered by the same fluids, and thus the Mannila granites also have minor topaz, some of which, however, seems to be primary.

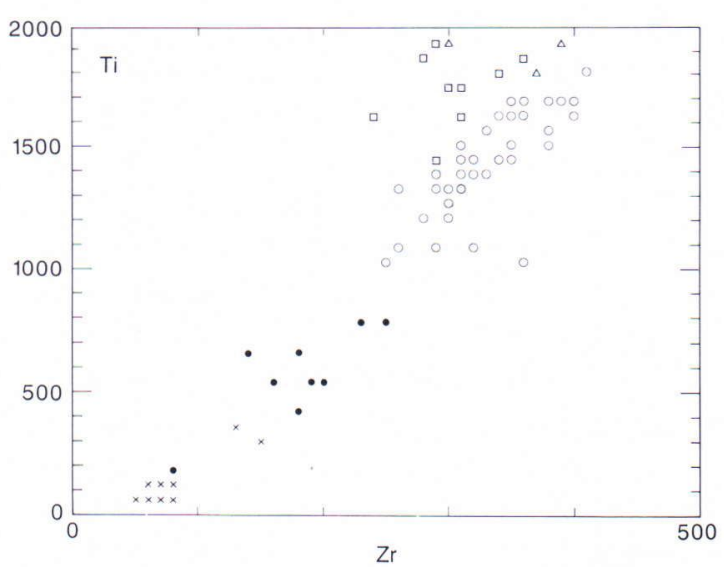

Fig. 10. Ti- $\mathrm{Zr}$ diagram showing the trends of the granites in the Kuusisuo area. Symbols as in Fig. 5. 
The Mannila granites are thought to be early crystallized parts or subphases of the same magma that formed the Kuusisuo granites. The coarse-grained, porphyritic type has intruded first along fractures in the porhyritic biotite rapakivi. The fine-even-grained type also occurs as dykes in the coarse-grained type, and must be younger. There are, however, no chilled borders between them. They have to a great extent intruded along the same channels. The evengrained type has abundant miarolitic cavities and pegmatitic bodies, indicating the separation of an aqueous phase. The medium-grained type with some phenocrysts could be a mingling product of the two other ones, because locally it has diffuse fragments of the porphyritic type or clusters of K-feldspar phenocrysts. This granite type makes up most of the Mannila granites.

The Kuusisuo granites are on the whole geochemically much more evolved than the Mannila granites. They have lower $\mathrm{Ti}-, \mathrm{Fe}-$ and $\mathrm{Mg}$ oxides, $\mathrm{Li}, \mathrm{Zr}, \mathrm{Ba}, \mathrm{Sr}$ and $\mathrm{La}$, and higher $\mathrm{CaO}$, $\mathrm{Na}_{2} \mathrm{O}, \mathrm{Nb}, \mathrm{F}$ and $\mathrm{Rb}$ than the older phases have (Table 2, Fig.11). The Fe-oxides, $\mathrm{Li}, \mathrm{Cu}$ and $\mathrm{Zn}$ increase abruptly from the medium-grained granite to the topaz-rapakivi and -greisen. $\mathrm{Na}$ increases in the Mannila and the medium-grained granites, but decreases strongly in the topazbearing phases. $\mathrm{SiO}_{2}$ changes in the same way, but very moderately. $\mathrm{K}_{2} \mathrm{O}$ decreases continuously.

The Kuusisuo stock reached an impermeable roof, which is shown by a relatively thin pegmatite of Stockscheider type at the contact with the older porphyritic rapakivi types. Water- and volatile-rich rest-solutions, also enriched in F, Li, $\mathrm{Rb}, \mathrm{Nb}$ and metals, were trapped under this roof, altering the already crystallized granite to topazrapakivi and -greisen. In some places the solutions were isolated in pockets and are now seen as the coarse-grained aggregates of quartz, feldspars, micas, fluorite, topaz and ore minerals. Now and then the fluid pressure rose so high, that it caused fractures in the overlying rocks. The solutions entered the fractures and caused alteration - the greisen veins - in the surrounding rapakivi. The fractures were sealed and the process started again. This was repeated a few times, producing several generations of greisen veins (cf. Plimer 1987).

The chemical compositions and the diagrams show that the Kuusisuo granites in drill hole $\mathrm{R}$ 12 are less fractionated than in holes $\mathrm{R} \mathrm{4,} \mathrm{R} 6$ and $\mathrm{R} 7$, where they reach their highest elevation. The Mannila granites reach the surface and resemble very much the granites in hole R 12 . They are thought to represent a block later uplifted relative to the Kuusisuo block.

The fractionation is reflected by the $\mathrm{K} / \mathrm{Rb}$ ratios, which are: Mannila granites 106, topazrapakivi in hole $\mathrm{R} 1288$, in $\mathrm{R} 659$ and in $\mathrm{R}$ 745 . The topaz-greisen has a $\mathrm{K} / \mathrm{Rb}$ ratio of 23 . Of the Mannila granites, the aplitic one in outcrop -1129 (Fig. 3) has the most evolved chemical composition. In many of the diagrams it lies in the same area as the Kuusisuo granites.

A profile of the penetrated parts of the granites in Kuusisuo is drawn in Figure 4. The drill holes go down to $80-100 \mathrm{~m}$ vertical depth. The contacts between the different rock types are all gradual and diffuse. Greisenized zones also occur in the topaz-rapakivi and vice versa. The greisen in drill hole $\mathrm{R} 7$ is much more altered and mineralized than in hole $\mathrm{R} 4$, the uppermost parts of which are eroded away.

The greisens with the strongest alteration that occur in the uppermost $2 / 3$ of drill hole $\mathrm{R} 7$ and in the center of hole $\mathrm{R} 4$ have $\mathrm{Li} 0.1-0.2 \%, \mathrm{Rb}$ $>0.1 \%$, F $2.5-5 \%$ and occasionally high $\mathrm{Zn}$, $\mathrm{Cu}$ and $\mathrm{Sn}$. In the upper part of $\mathrm{R} 4$ there are also high values of $\mathrm{Ag}$ (four analyses $8-13 \mathrm{ppm}$ ), As (600-1200 ppm) and W (500-800 ppm). A greisen body in the topaz-rapakivi in $\mathrm{R} 6$ has $\mathrm{Cu}$ $0.5 \%, \mathrm{Zn} 0.3 \%$ and As $0.5 \%$. None of the greisens are sufficiently enriched to be of economic interest.

The highest metal contents have been found in the greisen veins. One vein in Takamäki has Fe $18 \%$, Cu $1.2 \%$, Bi $0.2 \%$, Sn $0.04 \%$ and $\mathrm{Pb} 0.03 \%$, while another one has As $1.4 \%$ and Sn $0.04 \%$. The highest Sn-contents are in drill 


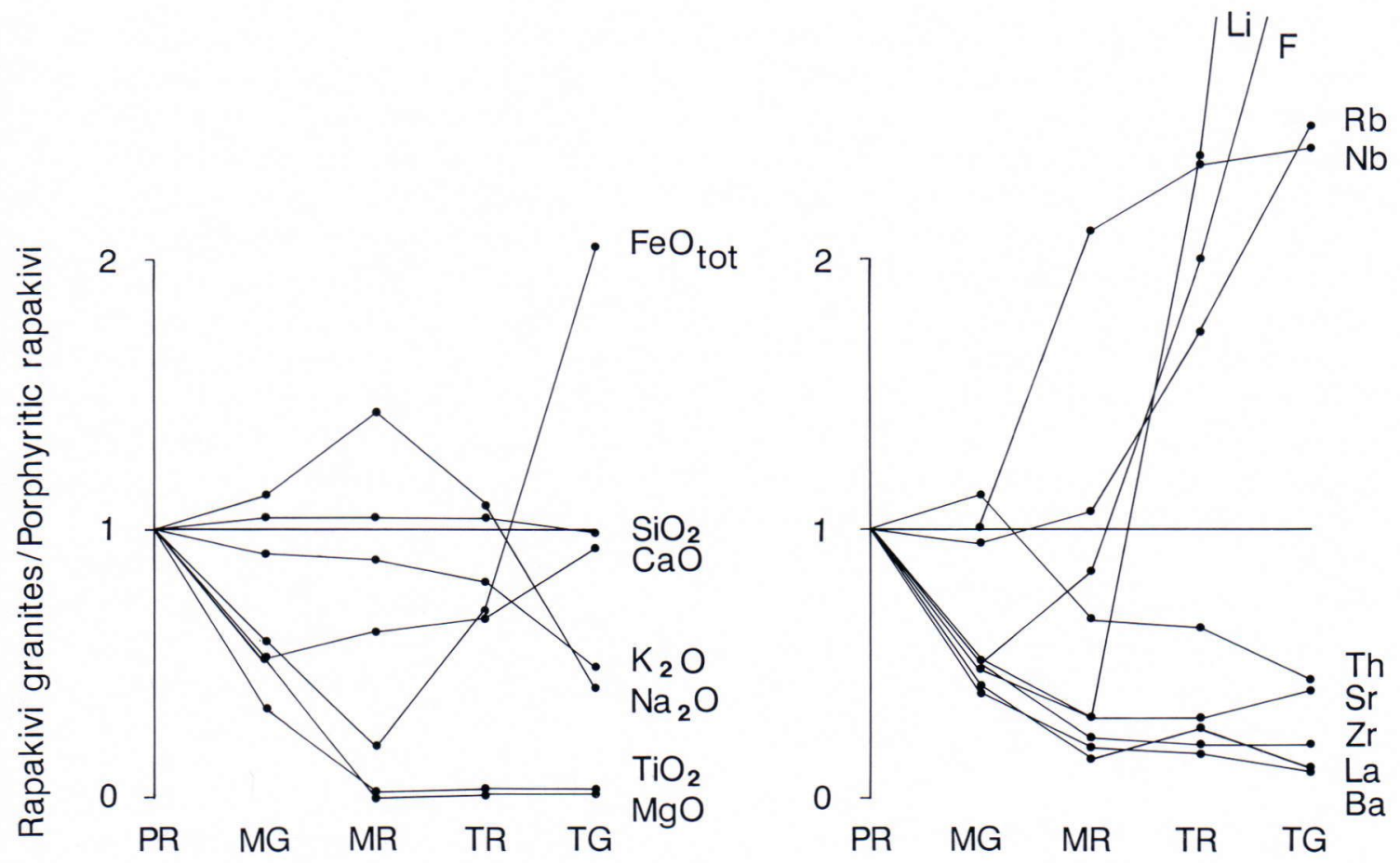

Fig. 11. The trends of some oxides and elements in the evolution of the rapakivi granites in the Kuusisuo area normalized against the porphyritic rapakivi. $\mathrm{PR}=$ porphyritic rapakivi, $\mathrm{MG}=$ Mannila granites, $\mathrm{MR}=$ medium-grained rapakivi, $\mathrm{TR}=$ topaz-rapakivi, $\mathrm{TG}=$ topaz-greisen .

hole R 10, while R 5, R 8 and R 9 has high $\mathrm{Cu}$ and $S n$ in some of their veins. The greisen veins in hole $\mathrm{R} 14$ have high $\mathrm{Zn}(0.1-0.7 \%)$.

There is no evident zonation of ore minerals in the greisen veins. Only in drill holes $\mathrm{R} 12, \mathrm{R}$ 13 and especially in $\mathrm{R} 14 \mathrm{Zn}$ is much more abundant than $\mathrm{Cu}$. This indicate that the veins are far away from the source (cf. Strong 1988). Otherwise the veins have varying amounts and ratios of $\mathrm{Sn}, \mathrm{Cu}, \mathrm{Zn}, \mathrm{As}, \mathrm{W}$ and $\mathrm{Bi}$. This probably depends on the several generations of greisen veins and on the block movements that seem to have taken place in the Kuusisuo area.

The rapakivi granites at Kuusisuo are of the same type and show the same characteristics and evolution as the Eurajoki and Kymi rapakivi granites described by Haapala (1977a, 1977b, 1988). One slight difference is the absence of Beminerals in the greisens at Kuusisuo. The evolu- tion at Kuusisuo is also much the same as in the models of mineralizations associated with granites, worked out by e.g. Pollard and Taylor (1986), Plimer (1987) and Strong (1988).

The rock association in the Kuusisuo area is the result of (at least) two different processes. The evolution trend: porphyritic rapakivi and porphyry aplites - Mannila granites - mediumgrained rapakivi - topaz-bearing rapakivi topaz-greisen, is evident from field observations and from the geochemical compositions (Table 2, Fig. 11). In particular the steady decrease of the Ti- and $\mathrm{Mg}$-oxides and the trace elements $\mathrm{Zr}$, $\mathrm{Ba}, \mathrm{Sr}$ and $\mathrm{La}$ in this series, is consistant with a primary magmatic differentiation trend. This primary trend is well shown by the diagram of the immobile elements $\mathrm{Ti}$ and $\mathrm{Zr}$ (Fig. 10).

The element distribution in the late stage Kuusisuo granites suggests that the primary trend is 
overprinted by late/post-magmatic processes (Fig. 11). F, Rb and $\mathrm{Nb}$ increase rapidly, beginning in the Mannila granites. $\mathrm{Li}, \mathrm{Fe}, \mathrm{Cu}$ and $\mathrm{Zn}$ increase even more steeply in the phases younger than the Mannila granites. These changes are due to the crystallization of the latest restsolutions and perhaps also to the influx of new solutions from outside. The solutions also cause the strong alteration reactions.

$\mathrm{Li}, \mathrm{F}$ and $\mathrm{Fe}$ are enriched in the dark mica (protholithionite), $\mathrm{F}$ also in the topaz and in the fluorite together with $\mathrm{Ca}$. $\mathrm{Fe}, \mathrm{Cu}$ and $\mathrm{Zn}$ increase because of the growing amounts of ore minerals. $\mathrm{Nb}$ can be incorporated in the mica and in cassiterite (e.g. Haapala 1988).

The medium-grained granite has very small amounts of dark mica-chlorite, which also explains the very low abundances of $\mathrm{Li}, \mathrm{Fe}, \mathrm{Ti}$ and $\mathrm{Mg}$. The slight increase of $\mathrm{Mg}$ and $\mathrm{Ti}$ in the topaz-rapakivi reflects the higher content of dark mica and chlorite.

$\mathrm{Rb}$ is concentrated in the latest rest-solutions as a result of magmatic differentiation and fractional crystallization. The amount of $\mathrm{Rb}$ in $\mathrm{K}$ feldspar and micas can rise to much higher values in the late stage differentiates (Heier and Billings 1970). This explains the high $\mathrm{Rb}$ in the latest phases although the total amount of K-feldspar is less.

The unusual composition of the late magmatic phases has also had its own effect on the mineralogical and chemical composition. The magma forming these late stage granites was rich in volatiles, especially water and F, which lowered both the viscosity and crystallization temperature of the magma and produced granites, that contain microcline and albitic plagioclase (Manning 1982). In Figure 11 this mineralogical composition is reflected as a decrease in $\mathrm{Ca}$ and increase in Na. The most obvious indications of the high F-content of the magma are the fluorite, topaz and F-rich mica, which characterize these rocks.

In the latest phases $\mathrm{Na}$ decreases, however, due to the breakdown of the plagioclase in the greisenizing processes. Ca increases because the amount of fluorite grows in the latest phases. $\mathrm{K}$ also decreases when the feldspars are destroyed.

The numerous alteration reactions; albitization, silicification, muscovitization, chloritization and topazization, show that the Mannila granites have also been affected by the same type of alteration that have produced the topaz-rapakivi and -greisen. In the Mannila area there was no elevation in the roof of the granite, where hydrothermal solutions could have concentrated in greater amounts. The Kuusisuo granites situated at fractures enabling the additional influx of solutions from outside.

According to Plimer (1987) the first subsolidus metasomatic event in the described type of granites is that of $\mathrm{K}$-feldspathization. This is usually overprinted by intense albitization in the apical parts of the granite. These albite-rich metasomatites commonly contain $\mathrm{Li}$ and $\mathrm{F}$ minerals, e.g. protolithionite, topaz, fluorite and abundant quartz. This albitized granite also undergoes greisenization in the apical parts. The greisens are tabular, stockwork or sheeted bodies. This process replaces feldspars with quartz, muscovite, Li-micas, F-minerals and ore minerals. The petrology and mineral assemblages suggest that these types of processes also have been acting at Kuusisuo.

The overlying rocks have been hydrofractured by the greisenizing fluids. The greisen veins have a scatter of orientations and abundances, but in different directions. The large size, the unusual abundance and the mineralization of the greisen veins in the outcrops at Takamäki and near drill hole R 10 in Konttimäki, might indicate other cusps like Kuusisuo.

Acknowledgements. Rautaruukki Oy financed the author's field work and the chemical analyses and all their exploration results were available. Mr Esa Mattila led the work at the company and was to a great help. Professor Ilmari Haapala and professor Carl Ehlers critically read the manuscript. Mrs Merja Puumala made the drawings and Mr Veikko Grönroos made the thin sections. The author wishes to thank them all. 


\section{References}

Anderson, J.L., 1983. Proterozoic anorogenic plutonism of North America. Geol. Soc. Am., Mem. 161, 133-154.

Bergman, L., 1981. Berggrunden inom Signilskär, Mariehamn och Geta kartblad. Summary: Pre-Quaternary rocks of the Signilskär, Mariehamn and Geta map-sheet areas. Explanation to the maps of Pre-Quaternary rocks, sheets $0034+0043,1012$ and 1021. Geological map of Finland, 1:100 000. Geol. Surv. Finland, $72 \mathrm{pp}$.

Collins, W.J., Beams, S.D., White, A.J. \& Chappell, B.W., 1982. Nature and Origin of A-type granites with particular reference to southeastern Australia. Contrib. Mineral. Petrol. 80, 189-200.

Edén, P., 1980. Hausjärvigraniternas och Ahvenisto biotitrapakivis kemi med speciell hänsyn till möjliga tennmineraliseringar. Unpublished M.Sc.-thesis, Åbo Akademi.

—, 1987. Geokemi, petrografi och Sn-Cu-Zn-As-greisenomvandlingar i en differentierad rapakivisvit i Ahvenistomassivet. Unpublished phil.lic- thesis, Åbo Akademi.

Elo, S. \& Tuomi, A., 1989. Gravimetric, magnetic and seismic interpretations of rapakivi massifs in southeastern Finland. In I.Haapala and Y.Kähkönen (Ed), Symposium. Precambrian granitoids. Petrogenesis, geochemistry and metallogeny. August 14-17, 1989. Helsinki, Finland. Geological Survey of Finland, Special Paper 8, 45.

Emslie, R.F., 1978. Anorthosite massifs, rapakivi granites, and late proterozoic rifting in North America. Precambrian Res. 7, 61-98.

Groves, D.I. \& McCarthy, T.S., 1978. Fractional crystallization and the origin of tin deposits in granitoids. Mineralium Deposita 13, 11-26.

Haapala, I., 1974. Some petrological and petrographic characteristics of rapakivi granite varieties associated with greisen-type $\mathrm{Sn}, \mathrm{Be}$ and $\mathrm{W}$ mineralization in the Eurajoki and Kymi areas, southern Finland. In: M. Stemprok (Editor), Metallization associated with acid magmatism, vol. 1, 159-169. Geol. Surv. Prague.

-, 1977a. Petrography and geochemistry of the Eurajoki stock, a rapakivi-granite complex with greisen-type mineralization in southwestern Finland. Geol. Surv. Finland Bull. 286, 128 pp.

- $1977 \mathrm{~b}$. The controls of tin and related mineralizations in the rapakivi-granite areas of southeastern Fennoscandia. Geologiska Före- ningens i Stockholm Förhandlingar 99, 130-142.

-, 1988. Metallogeny of the proterozoic rapakivi granites of Finland. In R.P. Taylor and D.F. Strong (Ed), Recent advances in the geology of granite-related mineral deposits. The Canadian Institute of Mining and Metallurgy, Special Volume 39, 124-132.

Heier, K.S. \& Billings, G.K., 1970. Rubidium. In Wedepohl,
K.H. (Ed), Handbook of Geochemistry, vol. II-4, 37D-37E. Springer-Verlag, Berlin-Heidelberg.

Johansson, B., 1984. Ahvenisto gabbro-anortositkomplex En petrografisk och mineralogisk undersökning. Unpublished M.Sc.-thesis, University of Helsinki.

Laitakari, I., 1987. Hämeen subjotuninen diabaasijuoniparvi. The Subjotnian diabase dyke swarm of Häme. Geologian tutkimuskeskus - Geological Survey of Finland, Tutkimusraportti - Report of Investigation 76, 99-116.

Laurén, L., 1968. En djupmodell av rapakivimassivet i SE Finland beräknad ur tyngdkraftsdata. Geologi 20, 89—91.

-, 1970. An interpretation of the negative gravity anomalies associated with the rapakivi granites and the jotnian sandstone in Southern Finland. Geologiska Föreningens i Stockholm Förhandlingar 92, 21-34.

Le Maitre, R.W., 1982. Numerical petrology: statistical interpretation of geoche mical data. Elsevier, Amsterdam, $281 \mathrm{pp}$.

Loiselle, M.C. \& Wones, D.R., 1979. Characteristics and origin of anorogenic granites. Geol. Soc. Am., Abstr. Programs $11,468$.

Manning, D.A.C., 1982. An experimental study of the effects of fluorine on the crystallization of granitic melts. In: Evans, A.M. (Editor), Metallization associated with acid magmatism, 191-203. John Wiley \& Sons, Chichester.

Mattila, E., 1983. Kuusisuon alueen iskuporaustutkimukset ja kairaus. Internal report OU 6/83, Rautaruukki Oy.

-, 1985. Kuusisuon greisen-alueen jatkokairaus. Internal report OU 3/85, Rautaruukki Oy.

— \& Peuraniemi, V., 1980. On geochemical prospecting for tin in Southern Finland. In: Tanskanen, H. (Editor), Methods of the geochemical mapping and boulder prospecting in the eastern part of the Baltic shield, 133-159. Geol. Surv. of Finland.

Miyashiro, A., 1978. Nature of alkalic volcanic rock series. Contrib. Mineral. Petrol. 66, 91-104.

Pearce, J.A., Harris, N.B.W.\& Tindle, A.G., 1984. Trace element discrimination diagrams for the tectonic interpretation of granitic rocks. J. Petrology 25, 956-983.

Peuraniemi, V., Mattila, E., Nuutilainen, J. \& Autio, H., 1984. Till and bedrock geochemistry in Sn exploration: A case study. J. Geochemical Exploration 21, 249-259.

Plimer, I.R., 1987. Fundamental parameters for the formation of granite-related tin deposits. Geol. Rundschau 76, $23-40$.

Pollard, P.J. \& Taylor, R.G., 1986. Progressive evolution of alteration and tin mineralization: Controls by interstitial permeability and fracture-related tapping of magmatic fluid reservoirs in tin granites. Scientific communica tions, Econ. Geology 81, 1795-1800.

Savolahti, A., 1956. The Ahvenisto massif in Finland. Bull. Comm. Géol. Finl. 174, 96 pp. 
Streckeisen, A.L., 1967. Classification and nomenclature of igneous rocks. N. Jb. Miner. Abh. 107, 144-214.

Strong, D.F., 1988. A review and model for granite-related mineral deposits. In Taylor, R.P. and Strong, D.F. (Ed), Recent advances in the geology of granite-related mineral deposits. The Canadian Institute of Mining and Metallurgy, Special Volume 39, 424-445.

Taylor, R.G., 1979. Geology of tin deposits. Developments in Economic Geology 11. Elsevier, Amsterdam, 543 pp.

Tischendorf, G., 1977. Geochemical and petrographic characteristics of silicic magmatic rocks associated with rareelement mineralization. In: Stemprok, M. (Editor), Metallization associated with acid magmatism, vol.2, 41-96. Geol. Surv. Prague.
Vaasjoki, M., 1977. Rapakivi granites and other postorogenic rocks in Finland: Their age and the lead isotopic composition of certain associated galena mineralizations. Geol. Surv. Finland Bull. 294, 64 pp.

—, M., Sakko, M. \& Rämö, T., 1989. New zircon age determinations from the Wiborg rapakivi batholith, Southeastern Finland. In: Autio, S. (Editor), Current research 1988. Geol.Surv.Finland, Special Paper 10, 41-42.

White, A.J.R. \& Chappell, B.W., 1983. Granitoid types and their distribution in the Lachlan Fold Belt, southeastern Australia. Geol. Soc. Am. Mem. 159, 21-34.

Received November 19, 1990

Revision accepted February 28, 1991 